\title{
Polymorphism of stearoyl-CoA desaturase (SCD1) gene in Indonesian local cattle
}

\author{
N. Hilmia ${ }^{1,2}$, R. R. Noor ${ }^{1}$, C. Sumantri ${ }^{1}$, R. E.Gurnadi ${ }^{1}$ and R. Priyanto ${ }^{1}$ \\ ${ }^{1}$ Animal Production and Technology, Faculty of Animal Science, \\ Bogor Agricultural University, Jl. Agatis, Darmaga Campus, Bogor16680 - Indonesia \\ ${ }^{2}$ Permanent Address: Animal Production, Faculty of Animal Science, Padjadjaran University, \\ Jl. Raya Bandung Sumedang Km 21 Jatinangor Sumedang 45363 - Indonesia \\ Corresponding E-mail: nena.hilmia@unpad.ac.id
}

Received October 05, 2016; Accepted January 24, 2017

\begin{abstract}
ABSTRAK
Stearoyl-Coa desaturase (SCD1) merupakan salah satu gen yang terlibat dalam perubahan asam lemak jenuh menjadi tidak jenuh. SNP pada gen SCD1 exon 5, yang mengubah asam amino valin menjadi alanin (Val293Ala) mempengaruhi komposisi asam lemak daging. Penelitian ini bertujuan untuk mengetahui keragaman gen SCD1 pada tiga sapi lokal Indonesia. Keragaman gen SCD1 diidentifikasi menggunakan 98, 20 dan 7 sampel DNA masing-masing sapi lokal Ciamis, Bali/Banteng dan Peranakan Ongole (PO). Keragaman SCD1 dianalisis berdasarkan SNP Val293Ala yang diidentifikasi menggunakan metode PCR_RFLP dengan enzim Aci1. Frekuensi alel dan nilai heterogositas dianalisis menggunakan program POPGENE 32. Hasil penelitian menunjukkan gen SCD1 pada sapi lokal Ciamis dan PO adalah polimorfik. Frekuensi alel T masing-masing sebesar 74,5\% dan $71,4 \%$ serta alel $\mathrm{C}$ masing masing sebesar $25,5 \%$ dan $28,6 \%$. Pada sapi lokal Ciamis terdapat tiga genotipe, yaitu TT, CT dan CC dengan frekuensi masing-masing sebesar 52\%, 44,9\% dan 3,10\%, sedangkan pada sapi PO terdapat dua genotipe, yaitu TT dan CT dengan frekuensi masing-masing sebesar 42,9\% dan 57,1\%. Gen SCD1 pada sapi Bali monomorfik. Keragaman gen SCD1 pada sapi Lokal Ciamis dan PO masing-masing sebesar 0,38 dan 0,44 termasuk dalam kategori sedang.

Kata kunci : sapi lokal Indonesia, gen SCD1, PCR_RFLP
\end{abstract}

\section{ABSTRACT}

Stearoyl-Coa desaturase (SCD1) gene is one of genes that involves in converting saturated fatty acids to unsaturated fatty acids. SNP at exon 5 in SCD1 gene that changes amino acid valine to alanine (V293A) has an influence to meat fatty acid composition. The aim of this research was to analyze SCD1 gene polymorphisms based on SNP V293A at exon 5 of three Indonesian local cattle. The identification of SCD1 gene polymorphisms was done by using 98, 20 and 7 DNA sample from Ciamis, Bali/Banteng, and Ongole Grade (PO) cattle, respectively. PCR_RFLP method with Acil enzim was carried out to identify SNP Val293Ala. Allelic frequencies and heterozygosity value were analyzed by using POPGENE32. The result showed that SCD1 gene at Ciamis local cattle and PO cattle were polymorphic. Their frequencies were $74.5 \%$ and $71.4 \%$ for $\mathrm{T}$ and $25.5 \%$ and $28.6 \%$ for $\mathrm{C}$, respectively. There were three genotypes on Ciamis local cattle i.e TT, CT and CC with their frequencies were $52 \%, 44.9 \%$ and $3.10 \%$, respectively. There were two genotypes on PO cattle i.e TT and CT with their frequencies were $42.9 \%$ and $57.1 \%$, respectively. Meanwhile, SCD1 gene in Bali cattle was monomorphic. Heterozygosity value of SCD1 gene in Ciamis and PO cattle were 0.38 and 0.44 , respectively. Their heterozigosities were categorized as medium.

Keywords : Indonesian local cattle,, PCR_RFLP, SCDI gene 


\section{INTRODUCTION}

The high consumption of red meat has been supposedly assosiated with diseases in human, such as cardiovacular, obesity, diabetes, neurological, skin damage and cancer (Miyazaki and Ntambi, 2003; Mauvoisin and Mounier, 2011). This is due to red meat contains considerable amount of saturated fatty acids (SFA), that is believed to increase unpleasant cholesterol in blood. Therefore, it is needed to increase unsaturated fatty acids (MUFA/PUFA) to get a healthier meat.

The one of genes which affects fatty acids composition in milk, adipose tissue, and meat is Stearoyl-CoA desaturase-1 (Milannesi et al. 2008; Orru et al., 2011). The biosynthesis of palmitoleyl-CoA and oleyl-CoA from palmitoylCoA and stearoyl-CoA are catalyzing by SCD1 enzyme, these substrates are important for the formation of triacylglycerols, phospholipids, cholesterol, and wax esters (Mauvoisin and Mounier, 2011). The expression of SCD1 gene affects fatty acid composition in phospolipid membrane, trigliseride dan cholesteryl ester, fat metabolism, and obese, it shows substantial role of SCD1 regulation in physiological processes (Scaglia et al., 2009)

Several previous studies indicated that there was high correlation between SCD1 gene variation that was caused by SNP Val293Ala at exon 5 , with saturated and unsaturated fatty acid ratio (SFA : PUFA/MUFA) in adipose tissue and meat (Taniguchi et al., 2004; Ohsaki et al., 2009; Barton et al., 2010; Orru et al., 2011). Allelic variation of SCD1 gene in crossbred of Wagyu $x$ Limousin, contributed to fat deposition, marbling, and composition of meat fatty acid (Jiang et al. 2008). SNP (Single Nucleotide Polymorphism) at exon 5 (T10329C/ T878C) that converts encoding amino acid Valine to Alanine (Val293Ala) causes difference intramuscular fatty acid composition in Japanese Black (Taniguchi et al. 2004; Ohsaki et al., 2009). Therefore, this SNP V293A has the potential as a marked assisted selection (MAS) for selection in beef cattle to get better meat quality.

This study was designed to identify SNP (single nucleotide polimorphisms) of SCD1 gene in Indonesian local cattle. Indonesia has many kinds of indigenous cattle such as Bali/Banteng cattle and local cattle likes Ongole Grade (PO), and Ciamis local cattle. There was no information about SCD1 gene in Indonesian cattle.

\section{MATERIALS AND METHODS}

\section{Materials}

Three breeds of Indonesian local cattle were used to identify polymorphisms of SCD1 genes, there were Ciamis local cattle, Bali/Banteng, and PO cattle. The identification of SCD1 gene polymorphisms were used 98, 20, and 7 DNA samples of Ciamis local cattle, Bali/Banteng, and PO cattle, respectively.

\section{Methods}

Single Nucleotide polymorphisms at SCD1 gene was analyzed using PCR_RFLP (Restricted Fragment Length Polymorphism), with Aci1 restricted enzyme that was cut off at GCGG/CGCC site. The primer that was used to amplify SCD1 gene at exon 5 were F:5'TGCCCATATGTATG GATACCG3' and R: 3'CCCAAAGGGGTT CATCATAC5'. These target were amplified with initial denaturation at $95^{\circ} \mathrm{C}$ for 5 minutes, followed by 33 cycles extended denaturation at $95^{\circ} \mathrm{C}$ for $30 \mathrm{~s}$, annealing at $56^{\circ} \mathrm{C}$ for $45 \mathrm{~s}$, extension at $72^{\circ} \mathrm{C}$ for 1 minute, and terminated by cooling down at $72^{\circ} \mathrm{C}$ for 5 minutes. The excision with restriction enzyme was performed with $5 \mu 1$ of PCR products mixed with $0.7 \mu 1 \mathrm{DW}$ (destilated water), $0.8 \mu \mathrm{l}$ buffer 0 and $0.5 \mu \mathrm{l}$ Acil enzyme then was incubated at $37^{\circ} \mathrm{C}$ for $16 \mathrm{~h}$. The PCR_RFLP product was evaluated by $1.5 \%$ electrophoresis agarose and visualized by UV transluminator. The product of PCR_RFLP consist of two band patterns on agarose electrophoresis which were $321 \mathrm{bp}$ and $263 \mathrm{bp}$ for $\mathrm{T}$ allele and $\mathrm{C}$ allele, respectively.

\section{Data Analysis}

Allelic, genotype frequencies and heterozygosity were calculated by Nei (1987) formula using POPGENE.32 program.

\section{RESULT AND DISCUSSION}

\section{SCD1 Gene Variation}

SCD1 gene target was covered at a part of exon 5 and whole of intron 6. It has successfully amplified with forward and reverse primer which was assigned to further PCR-RFLP analysis. PCR product was about 343 bp of length (Figure 1). PCR-RFLP was conducted using Acil enzyme, cut off nucleotide sequence at GCGG/CGCC site. PCR_RFLP analysis found two banding patterns on agarose electrophoresis which were $321 \mathrm{bp}$ ( $\mathrm{T}$ 


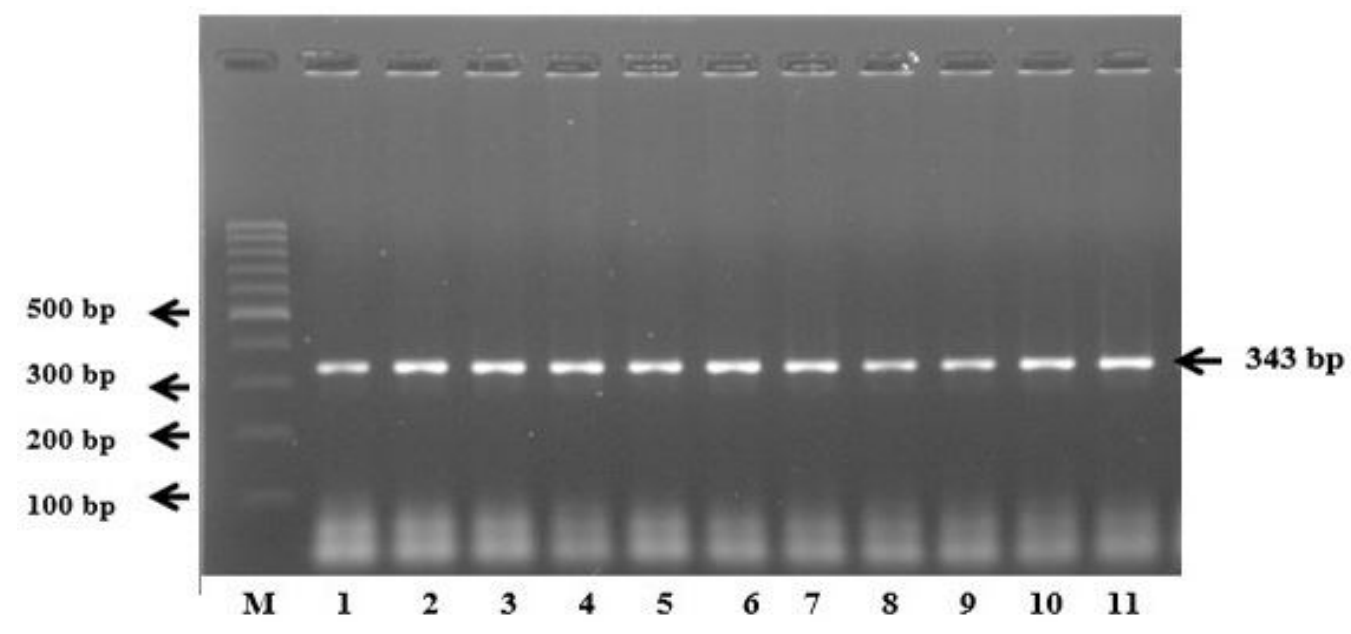

Figure 1. PCR Product of SCD1 Gene 343 bp of Length $. M=$ Marker 100bp, 1- $11=$ Sample number

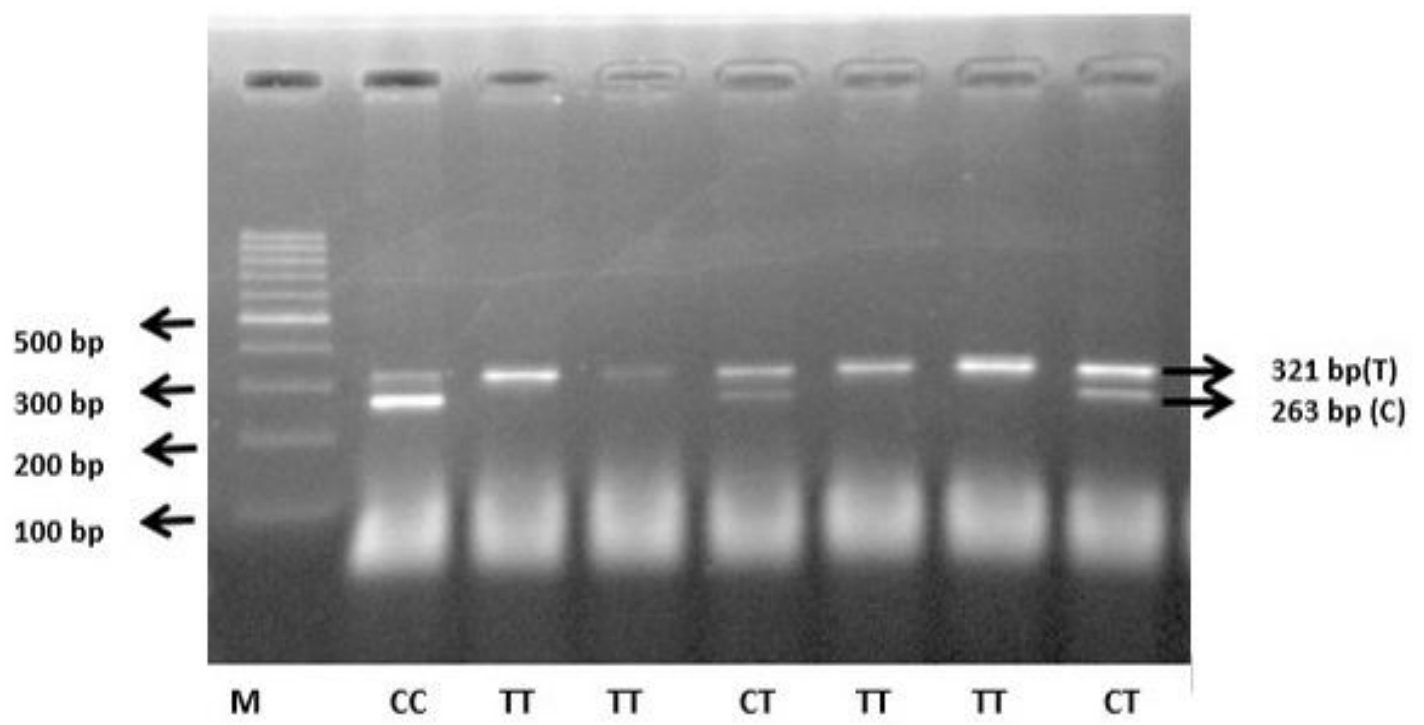

Figure 2. Band and Genotype of PCR- RFLP Product SCD1 Gene ( 321 bp and 263 bp)

allele) and $263 \mathrm{bp}(\mathrm{C}$ allele) as presented in Figure 2. The SNP target was 263 bp of length. Its position at $10329(\mathrm{~T}>\mathrm{C})$ encoding the changes amino acid of Valine to Alanine (Val293Ala) (NCBI no access AY241932.1). Based on this mutation, there were two alleles i.e $\mathrm{T}$ and $\mathrm{C}$ and three genotypes, namely TT, CT and, CC. The allele and genotype frequencies based on SCD1 gene in each breed were presented in Table 1.

Table 1 showed that higher frequency of $\mathrm{T}$ allele as compared to $\mathrm{C}$ allele was found in
Ciamis local cattle and PO cattle. In the present study, there was no SNP Val293Ala in Bali cattle. The frequency of $\mathrm{C}$ allele were low in Ciamis local cattle and PO cattle due to lower frequencies of $\mathrm{CC}$ genotype in Ciamis local cattle and that was not found in PO cattle.

These result corresponds with what has been reported by Orru et al. (2011) who analyzed 103 Simmental bulls that the frequency of $\mathrm{T}$ allele (70\%) was higher than $\mathrm{C}$ allele (30\%). In contrast, higher frequency of $\mathrm{C}$ allele than $\mathrm{T}$ allele was 
Table 1. Allele and Genotype Frequencies of SCD1 Gene in Indonesian Local Cattle

\begin{tabular}{|c|c|c|c|c|c|c|}
\hline \multirow{2}{*}{ Breed } & \multirow{2}{*}{$\mathrm{n}$} & \multicolumn{2}{|c|}{ Allele frequency } & \multicolumn{3}{|c|}{ Genotype frequency } \\
\hline & & $\mathrm{T}$ & $\mathrm{C}$ & $\mathrm{TT}$ & $\mathrm{CT}$ & $\mathrm{CC}$ \\
\hline Ciamis cattle & 98 & 0.7449 & 0.2551 & 0.5204 & 0.4490 & 0.0306 \\
\hline Bali/Banteng & 20 & 1 & 0 & 1 & 0 & 0 \\
\hline Ongole Grade (PO) & 7 & 0.7143 & 0.2857 & 0.4286 & 0.5714 & 0 \\
\hline
\end{tabular}

$\mathrm{n}=$ the number of samples

Table 2. Observed and Expected Heterozygosity Value of SCD1 Gene in Indonesian Local Cattle

\begin{tabular}{lrlll}
\hline \multirow{2}{*}{ Breed } & $\mathrm{n}$ & \multicolumn{3}{c}{ Heterozygosity } \\
\cline { 3 - 5 } & & \multicolumn{1}{c}{$\mathrm{H}_{\mathrm{o}}$} & $\mathrm{H}_{\mathrm{e}}$ & $\mathrm{Nei}$ \\
\hline Ciamis cattle & 98 & 0.4490 & 0.3820 & 0.3800 \\
Bali/Banteng & 20 & 0 & 0 & 0 \\
Ongole Grade (PO) & 7 & 0.5714 & 0.4396 & 0.4082 \\
\hline
\end{tabular}

$\mathrm{n}=$ the number of samples; $\mathrm{Ho}=$ Observed heterozygosity; $\mathrm{He}=$ Expected heterozygosity

reported by several researchers. Barton et al. (2010) found $55.5 \%$ vs $44.5 \%$ on Fleckvieh bulls and Taniguchi et al. (2004) who genotyped SCD1 gene by 3 SNPs including SNP at amino acid position V293A in Japanese Black cattle, revealed the average frequency of $\mathrm{C}$ allele and $\mathrm{T}$ allele were $59 \%$ and $41 \%$, respectively, that is due to, there are intensif selection forward to meat quality in this breed, particularly in marbling. The research of Milanesi et al. (2008) in Italian cattle revealed that $\mathrm{C}$ allele frequency at $\mathrm{T} 878 \mathrm{C}$ was spread out 89\% in Grey Alpine - 34\% in Italian Red Piedmintosa cattle, which showed that $\mathrm{C}$ allele in cows was higher that beef cattle. Taniguchi et al. (2004), Oka et al. (2007) and Ohsaki et al. (2009) who analyzed SNP in Japanesse Black cattle which revealed substitution $\mathrm{T}$ to $\mathrm{C}$ that changed the amino acid coding from Valine (V) to Alanine (A), caused differences in fatty acid composition. The AA (CC) genotype in Japanese Black steers indicate a higher MUFA percentage than $\mathrm{VV}(\mathrm{TT})$ and $\mathrm{VA}(\mathrm{CT})$, but the SCD1 polymorphism contributed $4 \%$ only, to overall MUFA variation (Taniguchi et al. 2004). There were differences among genotypes in meat fatty acid composition of Fleckvieh bull, AA (CC) and AV (CT) genotypes cattle have higher MUFA, lower SFA and therefore a higher MUFA / SFA ratio than VV genotype cattle (Barton et al. 2010). The SNP V293A in exon 5 was non synonimous mutation, due to change of encoded amino acid Valine to Alanine. Kumar et al., (2009) declare that a non-synonymous single nucleotide polymorphism (nsSNP) is a single amino acid substitution (AAS) in a protein sequence which could change the function of the protein, consequently, it can transform the phenotype.

The SCD1 gene in Bali cattle was monomorphic, there was no mutation in this site, Bali cattle is an Indonesian native cattle, that it is believed domesticated from Banteng. Indonesian goverment has been protect purity of Bali cattle, through cross breed prohibit of Bali cattle with others breed. Many studies showed that there were no variation (monomorphic) on quantitative gene in Bali cattle. Zulkarnain (2010) suggested that the growth hormone receptor gene (GRH/Alul1) in Bali cattle was monomorphic. Furthermore, Ishak et al. (2011) declared there was no differencess on nucleotide sequence (monomorphic) of FSH beta-subunit gene in Bali cattle.

SCD1 gene diversity values based on observation and expected heterozygosity of 
Ciamis local cattle population and PO cattle, were $0.449,0.571$ and $0.382,0.440$, respectively (Table 2). The heterozygosities value were a medium category.

\section{CONCLUSION}

The SCD1 gene in Ciamis local cattle and PO cattle were polymorphic, while it was monomorphic in Bali cattle. The SNP V293A was non synonimous mutation, due to encoding amino acid changed from Valine to Alanine. Frequency of C allele (mutation/ SNPV293A) was lower than $\mathrm{T}$ allele in Ciamis local cattle and PO cattle. Heterozygosity of SCD1 gene in Ciamis local cattle and $\mathrm{PO}$ cattle were in medium category.

\section{REFERENCES}

Barton, L.,T. Kott, D. Bureš, D.Rehak, R. Zahradkova and B. Kottova. 2010. The polymorphisms of stearoyl-CoA desaturase (SCD1) and sterol regulatory element binding protein-1 (SREBP-1) genes and their association with the fatty acid profile of muscle and subcutaneous fat in Fleckvieh bulls. Meat Sci 85: 15-20.

Ishak, A.B.L., C. Sumantri, R.R. Noor and I. Arifiantini. 2011. Identification of polymorphism of FSH beta-subunit gene as sperm quality marker in bali cattle using PCR-RFLP. J. Indonesian Trop. Anim. Agric. 36(4):221-227.

Jiang, Z.,J.J. Michal, D.J. Tobey, T.F. Daniels, D.C. Rule and M.D. MacNeil. 2008. Significant associations of stearoyl-CoA desaturase (SCD1) gene with fat deposition and composition in skeletal muscle Int. J. Biol. Sci. 4(6):345-351.

Kumar, P, S. Henikoff and Ng PC. 2009. Predicting the effects of coding nonsynonymous variants on protein function using the SIFT algorithm. Nat Protoc. 4(7):1073-1081.
Mauvoisin, D. and C. Mounier. 2011. Hormonal and nutritional regulation of SCD1 gene expression. Biochimie. 93:78-86

Milannesi, E., L. Nicoloso and P. Crepaldi. 2008. SCD gene polymorphisms in Italian cattle breeds. J. Anim. Breed. Genet. 125:63-67.

Miyazaki, M. and J.M. Ntambi. 2003. Role of stearoyl-coenzyme A desaturase in lipid metabolism. Prostaglandins, Leukotrienes and Essential Fatty Acids. 68:113-121

Nei, M,. 1987. Molecular Evolutionary Genetics. New York (US): Columbia University Press.

Ohsaki H., A. Tanaka, S. Hoashi, S. Sasazaki, K. Oyama and M. Taniguchi. 2009. Effect of SCD \& SREBP genotype on fatty acid compotition in adipose tissue of Japanese Black cattle herds. J. Anim Sci. 80(3):225232.

Oka, A., F. Iwaki, T. Dohgo, S. Ohtagaki, M. Noda, T. Shiozaki, O. Endoh and M. Ozaki. 2002. Genetic effect on fatty acid composition of carcass fat of Japanese Black Wagyu. J. Anim Sci. 80:1005-1011.

Orrù, L., G.F. Cifuni, E. Piasentier, M. Corazzin, S. Bovolenta, and B. Moioli. 2011. Association analyses of single nucleotide polymorphisms in the LEP and SCD1 genes on the fatty acid profile of muscle fat in Simmental bulls. Meat Science 87: 344-348.

Scaglia, N., Chisholm J.W. and Igal RA. 2009. Inhibition of StearoylCoA Desaturase-1 Inactivates Acetyl-CoA Carboxylase and Impairs Proliferation in Cancer Cells: Role of AMPK. PLoS ONE. 4: 1-14

Taniguchi, M., T. Utsugi, K. Oyama, H. Mannen, M. Kobayashi, Y. Tanabe, A. Ogino and S. Tsuji. 2004. Genotype of stearoyl-CoA desaturase is associated with fatty acid composition in Japanese Black Cattle. Mamm Genome. 14:142-148.

Zulkarnain. 2010. Identifikasi Keragaman Genetik Gen Receptor Hormon Pertumbuhan (GHR/Alu1) pada Sapi Bali. Thesis. Institut Pertanian Bogor. 